IZA DP No. 9864

Federal Minimum Wage Hikes Do Reduce Teenage Employment: The Time Series Effects of Minimum Wages in the US Revisited

Stephen Bazen

Velayoudom Marimoutou

April 2016 


\title{
Federal Minimum Wage Hikes Do Reduce Teenage Employment: The Time Series Effects of Minimum Wages in the US Revisited
}

\author{
Stephen Bazen \\ Aix-Marseille University, CNRS, EHESS \\ and IZA \\ Velayoudom Marimoutou \\ Aix-Marseille University, CNRS and EHESS
}

Discussion Paper No. 9864

April 2016

IZA

P.O. Box 7240

53072 Bonn

Germany

Phone: +49-228-3894-0

Fax: +49-228-3894-180

E-mail: iza@iza.org

\begin{abstract}
Any opinions expressed here are those of the author(s) and not those of IZA. Research published in this series may include views on policy, but the institute itself takes no institutional policy positions. The IZA research network is committed to the IZA Guiding Principles of Research Integrity.

The Institute for the Study of Labor (IZA) in Bonn is a local and virtual international research center and a place of communication between science, politics and business. IZA is an independent nonprofit organization supported by Deutsche Post Foundation. The center is associated with the University of Bonn and offers a stimulating research environment through its international network, workshops and conferences, data service, project support, research visits and doctoral program. IZA engages in (i) original and internationally competitive research in all fields of labor economics, (ii) development of policy concepts, and (iii) dissemination of research results and concepts to the interested public.
\end{abstract}

IZA Discussion Papers often represent preliminary work and are circulated to encourage discussion. Citation of such a paper should account for its provisional character. A revised version may be available directly from the author. 


\section{ABSTRACT}

\section{Federal Minimum Wage Hikes Do Reduce Teenage Employment: The Time Series Effects of Minimum Wages in the US Revisited}

In 2002 we published a paper in which we used state space time series methods to analyse the teenage employment-federal minimum wage relationship in the US (Bazen and Marimoutou, 2002). The study used quarterly data for the 46 year period running from 1954 to 1999. We detected a small, negative but statistically significant effect of the federal minimum wage on teenage employment, at a time when some studies were casting doubt on the existence of such an effect. In this note we re-estimate the original model with a further 16 years of data (up to 2015). We find that the model satisfactorily tracks the path of the teenage employment-population ratio over this 60 year period, and yields a consistently negative and statistically significant effect of minimum wages on teenage employment. The conclusion reached is the same as in the original paper, and the elasticity estimates very similar: federal minimum wage hikes lead to a reduction in teenage employment with a short run elasticity of around -0.13 . The estimated long run elasticity of between -0.37 and -0.47 is less stable, but is nevertheless negative and statistically significant.

JEL Classification: J21, J38, C22

Keywords: minimum wage, teenage employment, state space methods, unobserved components model

Corresponding author:

Stephen Bazen

Aix-Marseille School of Economics

Aix-Marseille University

2 Rue de la Charité

13002 Marseille

France

E-mail: stephen.bazen@univ-amu.fr

\footnotetext{
${ }^{*}$ We are grateful to Andrew Harvey for helpful discussions, and to Dan Hamermesh for comments and suggestions based on an earlier draft.
} 
In 2002 we published a paper in which we used state space time series methods to analyse the teenage employment-federal minimum wage relationship in the US (Bazen and Marimoutou, 2002). The study used quarterly data for the 46 year period running from 1954 to 1999. We detected a small, negative but statistically significant effect of the federal minimum wage on teenage employment, at a time when some studies were casting doubt on the existence of such an effect ${ }^{1}$. After a lull in the production of studies of the effects of minimum wages in the mid 2000s, there has been renewed interest in the issue in recent years. This has coincided with more widespread increases in state level minimum wages since the last federal hike that came into effect in 2009 (see Alegretto et al, 2011; Neumark et al, 2014).

In this note, we update our estimates using data spanning the period 1954 to 2015, bringing the sample to more than 60 years of quarterly data. The model treats the trend, cycle and seasonal components as stochastic. As explained in our earlier article, this approach allows for more flexibility than more rigid deterministic representations ${ }^{2}$ and also enables the use of proxy variables to be avoided. The estimated effects of minimum and average earnings on the teenage employment population ratio for the 62 year period are very similar in elasticity terms to those obtained in the earlier study. The robustness of this finding is rather surprising given the important changes that have occurred in the US teenage labour market in the last twenty years, in particular the fact that the teenage employment population ratio fell from $45 \%$ in 2000 to under 30\% after 2010 (its lowest level since 1950), with particularly sharp decreases after 2006 and during the financial crisis (see Figure 1).

The main finding presented here is that, other things equal, over the 62 year period from 1954 to 2015 federal minimum wage hikes reduced teenage employment, the short run elasticity being -0.13 . This is almost identical to estimate found in our earlier article. Due solely to a larger autoregressive coefficient, the long run elasticity is higher in absolute value at -0.4 .

In this note we begin by summarising the approach used in Bazen and Marimoutou (2002), and then re-estimate the same model over the extended data set up to the end of 2015 (section II). In order to check the robustness of the estimates, we re-estimate the model for different sub-periods in section III. Finally we suggest an explanation for the results obtained in section IV, and underline the fact that the results pertain to the effects on the employment of 16 to 19 year olds, before concluding.

\footnotetext{
${ }^{1}$ Studies appearing in the 1990s using cross-section and panel data produced conflicting results (see for example Neumark and Wascher, 1992 and Card, 1992).

${ }^{2}$ The stochastic representation contains the deterministic specification as a special case.
} 


\section{The Bazen-Marimoutou 2002 study}

Following Card and Krueger's (1995) critique of the 'consensus' that had grown up around the conclusion of Brown, Gilroy and Kohen's (BGK) (1982) survey that "a 10 per cent increase in the minimum wage reduced teenage employment by one to three per cent" (p.524), we undertook a re-examination of the time series approach to evaluating the impact of federal minimum wages on teenage employment. Cracks had already appeared in this consensus and were visible in the studies by BGK (1983) and Solon (1985) and were rigorously analysed by Card and Krueger (1995, Chapter 6). In our re-examination we found first that earlier approaches using deterministic trends, seasonal dummies, proxy variables and autoregressive error terms were unable to satisfactorily account for the time path of teenage employment. Second, using an unobserved components approach to modelling trend, cycle and seasonality in which these different components are treated as stochastic rather than deterministic (as set out in Harvey, 1989, and Harvey and Scott, 1994), produced a model that provided better in-sample and out-of-sample predictions of teenage employment than the approach adopted in BGK (1983) or Solon (1985). We also found that there was a negative and significant effect of federal minimum wages on teenage employment. This finding remained robust to the incorporation of different episodes of federal minimum wage fixing in the period between 1981 and 1997.

The Bazen-Marimoutou model of teenage employment - in which the teenage employment population ratio is expressed in logarithms and denoted EP - is a standard time series model, with trend $\left(\mu_{t}\right)$, seasonality $\left(\gamma_{t}\right)$, cycle $\left(\psi_{t}\right)$ and irregular $\left(\varepsilon_{t}\right)$ components, augmented to include the logs of the real value of the minimum (MW) and average (AW) wages $^{3}$ in a partial adjustment process:

$$
E P_{t}=\alpha E P_{t-1}+\beta_{1} M W_{t}+\beta_{2} A W_{t}+\mu_{t}+\gamma_{t}+\psi_{t}+\varepsilon_{t}
$$

In the traditional approach such as BGK (1983), the unobserved trend component is represented by a deterministic time trend (and sometimes its square) along with demographic proxy variables (such as the teenage population share); the cycle is represented by a proxy variable (usually the unemployment rate of prime age males); and the seasonality is captured by a set of dummy variables.

In this specification, the unobserved trend component is a random walk with drift:

\footnotetext{
${ }^{3}$ The series used were non-seasonally adjusted: average earnings of production and non supervisory workers; the CPI for All Urban Consumers and the employment population ratio for 16 to 19 year olds. All series were obtained from the Federal Reserve of St Louis Database.
} 


$$
\mu_{t}=\mu_{t-1}+\beta+\eta_{t} \quad \eta_{t} \sim N\left(0, \sigma_{\eta}^{2}\right)
$$

where $\beta$ is the slope $\mathrm{e}^{4}$ of the trend and $\eta_{t}$ is the stochastic component with zero mean. If the variance of the latter component $\left(\sigma_{\eta}^{2}\right)$ is zero, the trend is deterministic $\left(\mu_{t}=\mu_{t-1}+\beta\right)$ rather than stochastic. The cycle and seasonal components are also defined with a stochastic element, and reduce to a deterministic specification when the stochastic component has zero variance (see Harvey, 1989, for a more detailed treatment).

We estimated the model over various sub-periods in the period 1954:1 to 1999:2 in order compare its tracking performance with other approaches and to evaluate the robustness of the findings. Special attention was paid to different episodes of federal minimum wage hikes after 1981 which occurred in 1990-91 and 1996-97. The data set here extends the sample period to 2015 and includes the hikes implemented in the period 2007 to 2009.

\section{Estimates for the period 1954:1 to 2015:3}

The results for the whole data run up to the third quarter of 2015 are presented in the second column of Table 1. For purposes of comparison the model is estimated for the period 1954 to 1999 (column 1). Due to data revisions and in particular the periodic re-basing of the consumer price index, there are some minor differences in these results and those presented in Bazen and Marimoutou (2002). The trend, seasonal and cyclical components are all stochastic since the variances of the stochastic elements are non-zero. In Figure 2, the stochastic nature of these components is clearly visible. The contribution of the trend is substantial and underlies the decline in the teenage employment population ratio observed after 2000 - Figure 2(a). The amplitude of the cycle in teenage employment varies through the period, and becomes more pronounced from the mid 1990s (Figure 2(b)). Finally the stochastic nature of the seasonal component is quite clear from the plot of the individual seasonals in Figure 2(d) (these would be parallel horizontal straight lines in the deterministic case). The seasonal variation in teenage employment is less pronounced in 1980 compared to the 1960s, and even less so by the mid 2000s (Figure 2(c)).

Turning to the regression part of the model, the effect of the real federal minimum wage on employment is negative and significant $(t=-3.8)$. The estimated short run elasticity is -0.13 , rising in absolute value to -0.43 in the long run. While the short run elasticity is almost identical to the estimate for the period up to 1999:2, the long run elasticity is slightly larger in absolute terms than the estimate ${ }^{5}$ of -0.37 obtained with the revised data over the period 1954:1 to 1999:2 (column 1). The difference in these estimated long run elasticities is due solely to the size of the autoregressive coefficient. The negative, statistically significant effect

\footnotetext{
${ }^{4}$ The slope can also be treated as stochastic: $\beta_{t}=\beta_{t-1}+\xi_{t}$ where $\xi_{t} \sim N\left(0, \sigma_{\xi}^{2}\right)$. The slope is fixed $\left(\beta_{t}=\beta_{t-1}\right)$ when $\sigma_{\xi}^{2}=0$. However in all cases here the slope was found to be fixed.

${ }^{5}$ The estimated short and long run elasticities were -0.12 and -0.27 in Bazen and Marimoutou (2002).
} 
of the minimum wage on teenage employment is based on the coefficient on the minimum wage variable which is almost identical in the period up to 2015 as that for 1954-99. In the context of the model used, the earlier conclusion that federal minimum wage hikes have a negative effect on teenage employment is reinforced.

\section{Robustness checks}

The estimated effect of minimum wages is negative and statistically significant, and the short run elasticity appears to be highly stable (and this is supported by the predictive failure test). This stability is confirmed when we add the variables $\left(E P_{t-1}, M W_{t}, A W_{t}\right)$ each multiplied by a dummy variable equal to one for observations after 1999(2) - Table 1, column 3. The $t$ statistics for the coefficients are all less than one in absolute value. In order to further check the robustness of the results, the model is re-estimated for two sub-periods. The first is defined so as to exclude the most recent hikes in the federal minimum wage and runs from 1954:1 to 2006:4. The federal minimum was left unchanged at $\$ 5.15$ from 1997:3 and its real value had declined by some seven per cent before the increase implemented in July 2007. The results are presented in column (4) of Table 1. As with the full sample period, the unobserved components are all stochastic with non-zero variances for the period 1954:1 to 2006:4. The estimated short run minimum wage elasticity is -0.12 and significant $(t=-3.62)$, and the long run estimate -0.37 (slightly smaller in absolute value than that for the full period).

We next incorporate the increases that were implemented in the period 2007 to 2009, taking the federal minimum from $\$ 5.15$ first to $\$ 5.85$ in July 2007, then to $\$ 6.55$ in July 2008 and finally to $\$ 7.25$ in July 2009, where it has remained until the time of writing (March 2016). Although the minimum wage increased by $41 \%$ in nominal terms between June 2007 and July 2009, it is probably more relevant to note that it increased by $24 \%$ between July 2007 and July 2009, representing a real increase of nearly $20 \%$ over a two year period. Given the lags involved in the effect that shocks have on teenage employment, the model is estimated up to the end of 2010 (around 18 months after the last minimum wage hike) and the estimates are presented in column (5) of Table 1. The estimated short run elasticity hardly changes $(-0.127, t=-3.85)$ but the long run value is higher in absolute value $(-0.47)$ due solely to a larger autoregressive coefficient.

\section{Interpretation}

On the basis of these time series estimates, it is difficult to deny that hikes in the federal minimum wage have a negative impact on teenage employment. The result holds over a very long data run of more than 60 years, as well as for shorter sub-periods in which the real value of the minimum wage changed by varying amounts. The advantages of using time series data as a means of evaluating the effects of minimum wages however have been ignored or understated in much of the literature since 1990. Yet it is well-known that it is very difficult to identify the effects of federal hikes using other forms of data due to their 
correlation with any common time effects (see for example, and Bazen and Le Gallo, 2009). The estimates presented here provide clear evidence that federal hikes have a negative effect on teenage employment.

Taking the conclusion of the current paper as given, it is important to bear in mind that it concerns the employment of 16 to 19 year olds, a group whose employment population ratio has declined from $50 \%$ in the 1970 s to less than $30 \%$ currently, and the minimum wage is not responsible for this trend decline. The impact on other groups in the labour force may be more relevant for assessing the importance of any employment effects associated with minimum wages (see Belman et al, 2015).

Unlike countries such as France and the United Kingdom, federal minimum wage hikes are rare events in the United States and their impact is reversed by the subsequent erosion of the real value of the minimum. The duration between federal hikes after the 1981 increase was 9 years; after the 1991 increase five and half years, and after the 1997 one, ten years. It has been six and half years since the last increase in 2009 at the time of writing. In between federal hikes, the minimum rates set in certain states become the relevant binding minimum wage. One possible reason behind the effect detected here is that in states where the only binding minimum wage is the federal rate, real labour costs for minimum wage workers are declining between hikes and are subject to substantial discrete increases when the next hike comes along. For an employer of low wage labour in a state where there is no binding state minimum, it is not costly to base hiring and firing decisions on movements in the real value of the federal minimum wage due to the low frequency of federal level hikes.

\section{$V$ Conclusion}

This note updates and confirms the findings of our earlier study of the impact of minimum wages using time series data. The time series model used satisfactorily tracks the path of the teenage employment-population ratio over a period of more than 60 years, and yields a consistently negative and statistically significant effect of federal minimum wages on teenage employment. One conclusion is clear: federal minimum wage hikes lead to a reduction in teenage employment with a short run elasticity of around -0.13 . The estimated long run elasticity of between -0.37 and -0.47 is less stable, but is nevertheless negative and statistically significant. Unlike analyses using state level panel data where the effect of federal minimum wages cannot be separated out from fixed time effects, its effect is clearly identified in the model used. 


\section{References}

S. Allegretto, A. Dube and M. Reich (2011) Do minimum wages really reduce teen employment? Accounting for heterogeneity and selectivity in state panel data, Industrial Relations, 50 (2), 205-240.

S. Bazen and V. Marimoutou (2002) Looking for a needle in a haystack ? A re-examination of the time series relationship between teenage employment and minimum wages in the United States, Oxford Bulletin of Economics and Statistics, 64, 699-724.

S. Bazen and J. Le Gallo (2009) "The state-federal dichotomy in the impact of minimum wages on teenage employment in the US", Economics Letters, 105, September, 267-269.

D. Belman, P. Wolfson and K. Nawakitphaitoon (2015) Who is affected by the minimum wage? Industrial Relations, 54 (4), 582-621.

C. Brown, C. Gilroy and A. Kohen (1982), "The effect of the minimum wage on employment and unemployment", Journal of Economic Literature, 20, 487-528.

C. Brown, C. Gilroy and A. Kohen (1983), "Time series evidence on the effect of the minimum wage on teenage employment and unemployment", Journal of Human Resources, Winter, 18, 3-31.

D. Card (1992) Using regional variation in wages to measure the effects of the federal minimum wage, Industrial and Labor Relations Review, 46, 22-37.

D. Card and A. Krueger (1995) Myth and measurement: the new economics of the minimum wage, Princeton University Press, Princeton, NJ.

A. Harvey (1989) Forecasting, structural time series models and the Kalman filter, Cambridge University Press, Cambridge.

A. Harvey and A. Scott (1994) Seasonality in dynamic regression models, Economic Journal, 104, 1324-1345.

D. Neumark, I. Salas and W. Wascher (2014) Re-visiting the minimum wage-employment debate: Throwing the baby out with the bathwater? Industrial and Labor Relations Review, 67 (2), 608-648.

D. Neumark and W. Wascher (1992), Employment effects of minimum wages and subminimum wages: panel data on state minimum wage laws, Industrial and Labor Relations Review, 46, 55-81.

G. Solon (1985), The minimum wage and teenage employment: the role of serial correlation and seasonality, Journal of Human Resources, 20, 292-297. 
Table 1 Teenage employment population ratio regressions 1954:1 to 2015:3






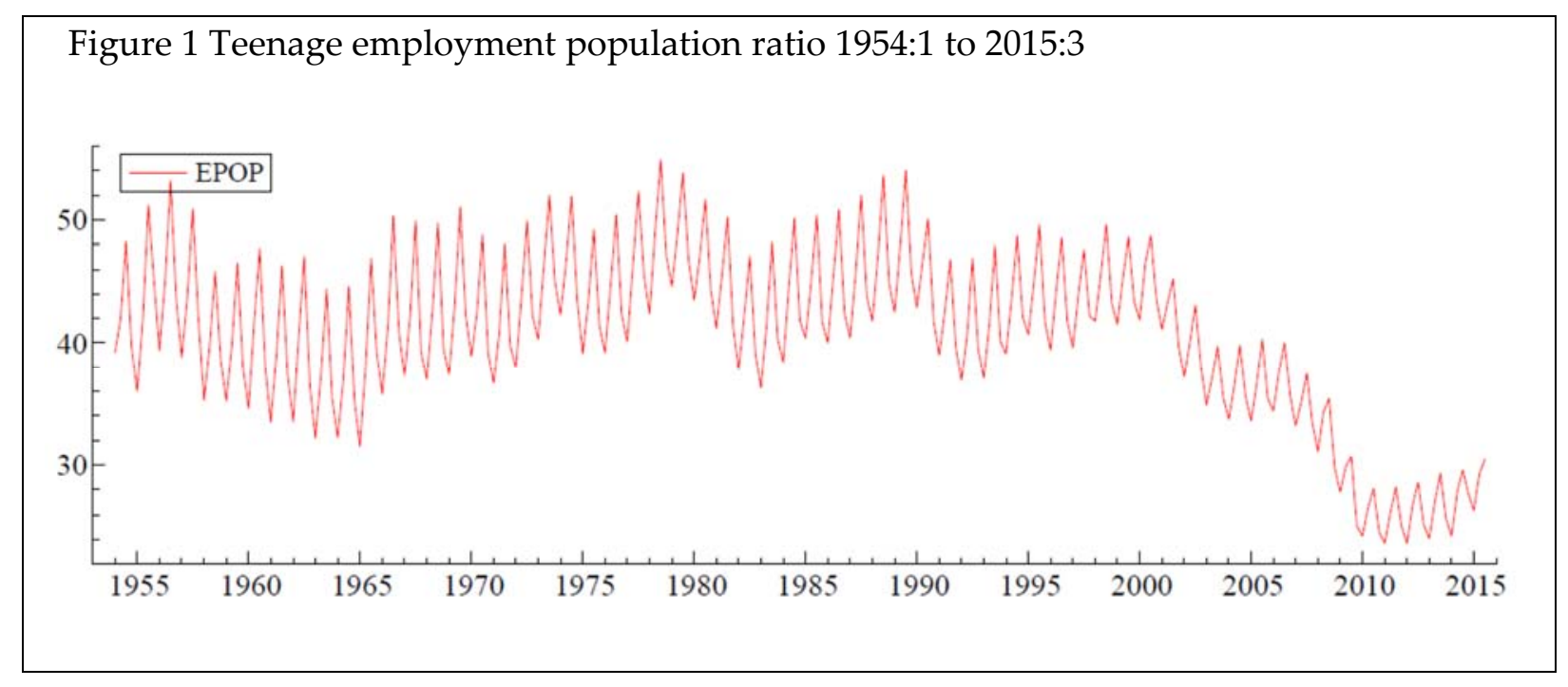

Figure 2 Trend, cyclical and seasonal components 1954:1 to 2015:3

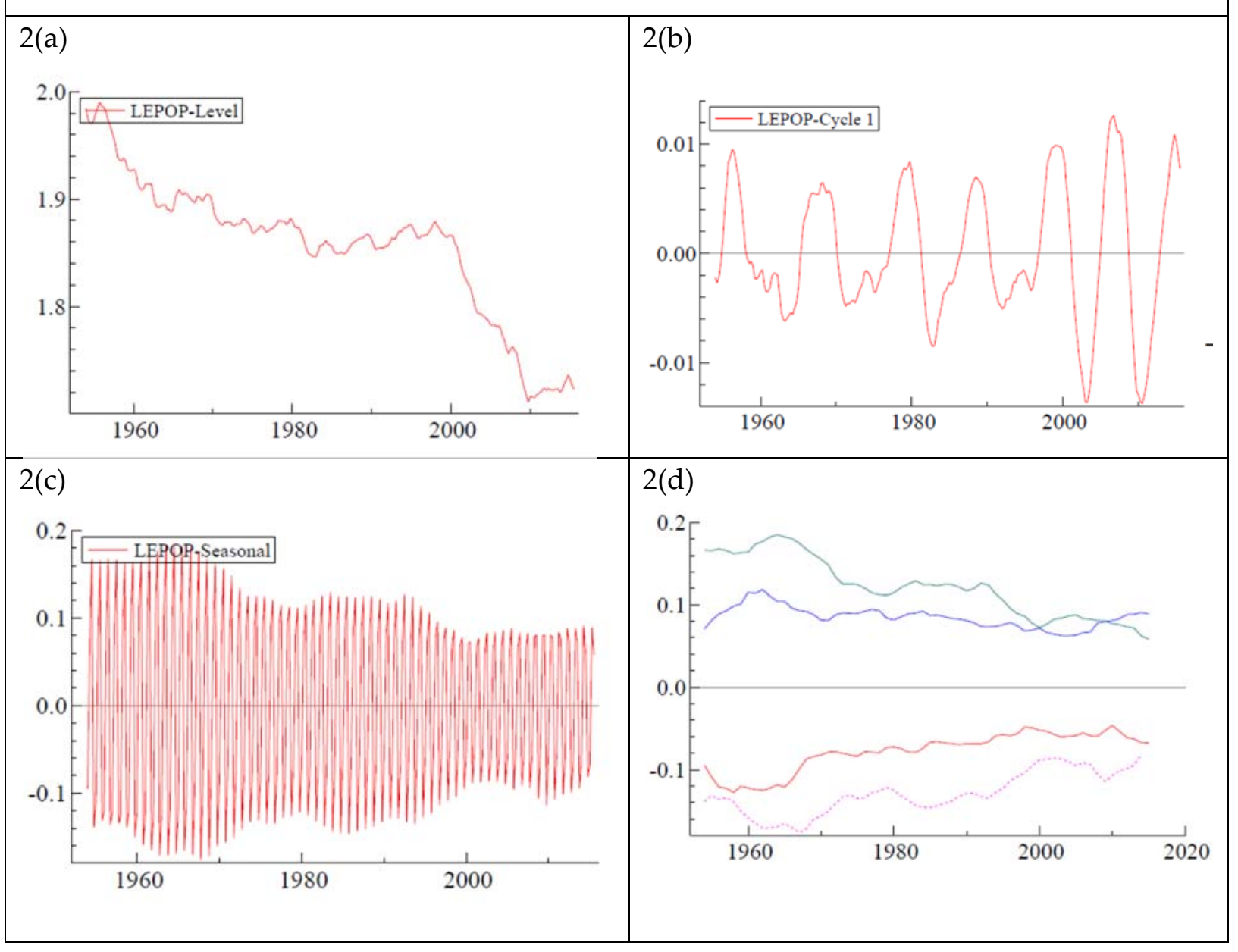

